\section{Mye teori om faglig skjønn}

Helene Hanssen, red

Faglig skjønn og brukermedvirkning

206 s. Bergen: Fagbokforlaget, 2010.

Pris NOK 298

ISBN 978-82-450-0866-1

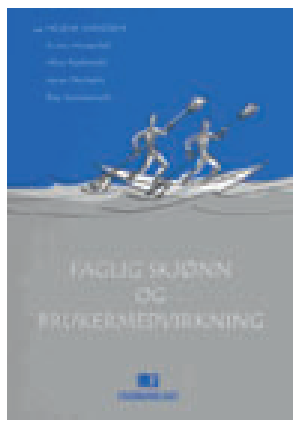

Denne boken tar opp viktige tema. Innen dagens helseog sosialtjeneste med økt vektlegging av mål- og resultatstyring, rapportering og dokumentasjon er det spesielt viktig å synliggjøre at skjønnsutøvelse er kjernen i helsearbeid og sosialt arbeid, og at organisering og ledelse utgjør viktige rammebetingelser for skjønnsutøvelse. De fem forfatterne har bakgrunn i sykepleie, sosialt arbeid og jus. Som målgruppe angis studenter innen helse- og sosialfag på høgskoleog universitetsnivå og fagpersoner i helseog sosialtjenesten.

Det er sju kapitler. Det første er skrevet av alle forfatterne i samarbeid, de øvrige kapitlene av enkeltforfatterne. I første kapittel drøfter forfatterne teoretisk faglig skjønn og skjønnsutøvelse $\mathrm{i}$ helse- og sosialfaglig arbeid, og de diskuterer forholdet mellom rettsanvendelsesskjønn og faglig skjønn. I andre kapittel gjennomgås det rettslige grunnlaget for pårørendeinvolvering $i$ helsetjenesten. Forfatteren beskriver hvordan rettsregler setter rammer for hva som kan eller skal bestemmes, og helsepersonells handlefrihet innen disse rammene. Disse to kapitlene er gode og formidler nyttig kunnskap.

De påfølgende kapitlene er ujevne. At de ulike kapitlene står litt for seg selv, og at det er en del gjentakelser, er ikke så farlig. Hovedinnvendingen er at kapitlene er for teoretiske med for mange ulike teoretiske perspektiver som ikke integreres, og at det i for liten grad knyttes an til den solide teoretiske gjennomgangen innledningsvis. For eksempel har et av kapitlene 75 referanser til forfattere innen bl.a. psykologi, filosofi, sosiologi, medisin og sykepleie. Forfatterne refereres kort, ofte i form av utvalgte sitater, men perspektivene settes $i$ liten grad inn i en større sammenheng, og kapittelforfatterens egen stemme forsvinner. Språket er uklart, og det er vanskelig å få tak i budskapet. I to kapitler tar forfatterne utgangpunkt $i$ empiriske studier fra praksisfeltet (demensomsorg og sosialt arbeid). Dette fungerer godt, og de formidler interessante resultater. Forfatterne lykkes imidlertid ikke helt med å knytte empirien til teorien og greier derved ikke å løfte frem fra praksisfeltet gode eksempler på skjønnsutøvelse knyttet til interessante utfordringer og dilemmaer.
Flere kapitler har godt språk og tydelig fremstilling, mens i andre blir teksten ordrik og enkelte ganger uklar. Et lite irritasjonsmoment er at alminnelige utsagn ofte belegges med referanser, som noen ganger også kan virke søkt.

Jeg vil anbefale bokens to første kapitler for målgruppen som angis. Andre kapitler vil også kunne ha interesse. De to første kapitlene bør avgjort også være nyttige for politikere, ledere og administratorer innen helse- og sosialfeltet ved at de tydeliggjør viktige (ramme)betingelser for å kunne gjøre et godt klinisk arbeid på praksisnivået.

\section{Sissel Steihaug}

Avdeling helsetjenesteforskning SINTEF

\section{Er velferdsstaten avhengig av tette grenser?}

Grete Brochmann, Anniken Hagelund Velferdens grenser

392 s, ill. Oslo: Universitetsforlaget, 2010.

Pris NOK 379

ISBN 978-82-15-01617-7

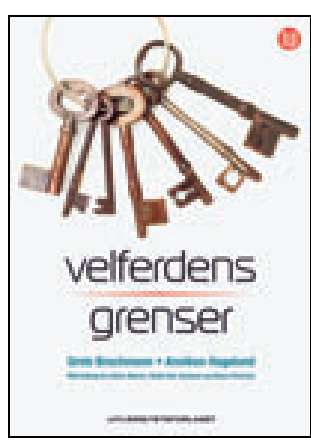

Dersom du trenger en detaljert oversikt over innvandringspolitikken i de tre skandinaviske landene etter 1945, er dette boken for deg. Om du i tillegg trenger en diskusjon av motsetningene mellom velferdsstaten og

innvandring fra utviklingsland, er dette rette kilden. Boken handler nemlig ikke om grensene for velferdsstaten, men om velferdsstatens behov for å vokte sine statsgrenser.

Dette er sluttrapporten fra det forskningsrådsfinansierte prosjektet Innvandringens velferdspolitiske konsekvenser. En nordisk kunnskapsoppsummering. Karin Borevi har skrevet det svenske bidraget, Heidi Vad Jønsson og Klaus Petersen det danske.

Her er store mengder stoff. Det jeg savner, er for det første analyser og teorier. For det andre er oppsummeringene sparsomme. Forfatterne mener nok at de tre skandinaviske velferdsstatene $\mathrm{i}$ all hovedsak har tålt påkjenningene med store mengder ufaglærte og lite integrerte innvandrere. Den velferdspolitiske hovedlinjen med like rettigheter for alle bosatt i landet, er beholdt med bare små endringer.

Derimot er innvandringspolitikken blitt skrittvis forandret, fra åpne grenser i de første par decenniene etter krigen til dagens nøye siling av flyktninger. Dette har skjedd ulikt i de tre landene, og de som er interes- sert i detaljer, finner masse stoff her. Men igjen er konklusjonene forsiktige og oppsummeringene vage, til tross for mye dramatikk i emnet.

Det kan virke som om forfatterne er innstilt på å skrive den offisielle historien om innvandringen i de tre skandinaviske landene i etterkrigstiden. De støtter den offisielle innvandringspolitikken. Hva de ellers mener, forblir utydelig. Derfor blir dette en bok for de spesielt interesserte.

\section{Bjørgulf Claussen}

Institutt for helse og samfunn

Universitetet i Oslo

\section{Debattbok om barns helse}

Frank Lindblad, Carl Lindgren Välfärdslandets gåta

Varför mår barnen inte lika bra som de har det? 168 s, tab, ill. Stockholm: Carlsson Bokförlag.

2010. Pris SEK 249

ISBN 978-91-7331-220-2

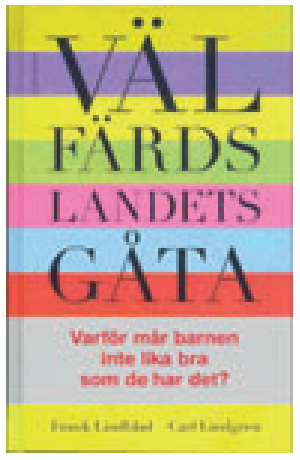

Med denne boken ønsker forfatterne, en barnelege og en barnepsykiater, å sette søkelyset på det paradokset at barn i økende grad, og økende med alderen, angir at de føler seg utilpass, samtidig som velferdssamfunnet utvikles med stadig flere goder for befolkningen. Mer velferd gir altså ikke mer helse, men kanskje til og med tvert imot. Kan det tenkes at vi trenger en ny forståelse av helse og velferd?

Det er ingen definert målgruppe, men forfatterne henvender seg til alle som har interesse for barn, helse og velferdspolitikk. $\mathrm{Vi}$ inviteres til diskusjon og til å tenke nytt. Det er tre hoveddeler: Hur mår barnen, Hur mår samhället og Vägen framåt. Hver hoveddel har underkapitler med tilhørende litteraturreferanser.

I den første hoveddelen beskriver forfatterne sitt utgangspunkt, nemlig barns subjektive beskrivelse av egen helsetilstand, både fysisk og psykisk, slik det kommer frem både i klinisk arbeid og gjennom gjentatte store befolkningsundersøkelser. Barn og unge rapporterer i økende grad om tristhet og depresjon, hodepine, vondt i magen og andre psykosomatiske plager, til tross for at svenske barn objektivt sett aldri har vært friskere eller hatt tilgang på et bedre helsevesen.

I andre hoveddel setter man søkelyset på velferdssamfunnet: Hva gjør det med oss at samfunnet tar så stort ansvar for vår helse? 
Hvor blir det av vårt eget ansvar? Fra et ungdomspsykiatrisk perspektiv er dette sentralt, nettopp fordi utviklingen av autonomi, selvstendighet og ansvar er denne aldersgruppens primære utviklingspsykologiske oppgave. Her tar forfatterne utgangspunkt $\mathrm{i}$ «ohelsans nollvision» og begrepet «nolltolerans». Debatten er velkjent også hos oss, man refererer bl.a. til Per Fugellis bok 0-visjonen fra 2003 (1), men i denne sammenhengen tar de utgangspunkt i betydningen for barn og ungdoms helse. Begreper som «hälsomani» og «välfärdsapati» blir sentrale.

I den siste delen samler forfatterne sine refleksjoner og beskriver en biopsykososial modell for forståelse av «ohelsa». «Vägen framåt» gir ingen løsninger. Men nødvendige endringer må baseres på en god analyse av de utfordringene vi står overfor, og den blir levert.

Forfatterne bruker sin kombinasjon av lang klinisk erfaring og forskningsbasert kunnskap til å sette fingeren på vesentlige helsepolitiske spørsmål. Språket er lettfattelig, også for en leser uten særskilt kjennskap til svensk. Selv om man gjennomgående refererer til svenske undersøkelser og svenske forhold, er forholdene i våre to land såpass like at det er all grunn til å anta at det meste også er gangbart hos oss.

\section{Jannike Engelstad Snoek}

Senter for psykisk helse barn og ungdom Oslo universitetssykehus

\section{Litteratur \\ 1. Fugelli, P. 0-visjonen. Oslo: Universitetsforlaget 2003}

\section{Standardiserte behandlere}

Anette Søgaard Nielsen

Behandlingsarbejde i team

Teambaseret behandling med

behandlerrotation. 176, tab, ill. København:

Hans Reitzels Forlag, 2010. Pris DKK 250

ISBN 978-87-412-5399-2

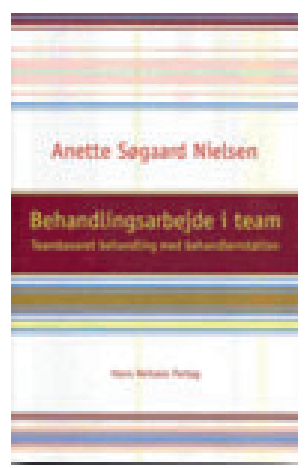

I denne lille boken forteller forfatteren en solskinnshistorie om et vellykket tysk poliklinisk behandlingskonsept for alkoholikere som ble kopiert i Odense med tilsynelatende meget godt resultat. Det dreier seg om langvarige behandlingopplegg innenfor en kognitiv atferdsterapeutisk referanseramme, som er den vanligste måten å arbeide terapeutisk med rusmiddelavhengige på. Det ambisiøse behandlingsmålet om å holde pasienten rusfri søkes oppnådd med nokså enkle metoder: motiverende intervjuer og praktisk problemløsning basert på en individuell og omforenet målstruktur. Det nye her er at terapeuten erstattes med et tverrfaglig team.

Betyr ikke det langt flere behandlerressurser? Poenget er selvsagt at det ikke gjør det; antall ansatte og antall pasienter forblir det samme. Grepet er at personalet systematisk bytter på å foreta pasientsamtalene. Dette presiserer man for øvrig allerede i undertittelen: Teambaseret behandling med behandlerrotation.

Den entusiastiske forfatteren, Anette Søgaard Nielsen, mener at en poliklinikk kan ha mye å vinne på en overgang til teambasert behandling med behandlerrotasjon. Særlig fremhever hun bedre kontinuitet $\mathrm{i}$ behandlingen (fordi den ikke avbrytes av behandlernes sykdom eller feriefravær), bedre utnyttelse av behandlernes tverrfaglige kompetanse, lettere å unngå dysfunksjonelle pasient-behandler-relasjoner (som er ganske vanlig i rusbehandling) og bedre håndtering av pasientenes eventuelle sosiale angst (fordi de hele tiden må forholde seg til flere personer). Videre gir et slikt opplegg behandlerne bedre grunnlag for gode faglige diskusjoner om pasientenes likheter og forskjeller

Det sier seg selv at dette opplegget krever god styring og koordinering, og at det i utgangspunktet må være en viss størrelse på poliklinikken for at det skal kunne la seg gjennomføre. I Odense ble det opprettet fire team med fire til seks behandlere i hvert, til sammen minst 20 behandlere. Men det er sikkert mulig å operere med bare ett eller to team. For den nye norske konstruksjonen TSB - tverrfaglig spesialisert behandling (av pasienter med rusproblemer og rett til nødvendig helsehjelp) - kan dette kanskje være en inspirasjonskilde $\mathrm{i}$ utviklingsarbeidet, $\mathrm{i}$ alle fall for de pragmatisk anlagte spesialistene.

Forfatteren gir ganske detaljerte beskrivelser av hvordan man gikk frem i Odense, samtidig som boken absolutt ikke er teoriløs - den har mange gode og nyttige referanser til behandlingslitteraturen generelt. Hvor generaliserbart dette er som behandlingsform, f.eks. til andre problemområder der kognitiv atferdsterapi kan være aktuelt, er det ikke mulig å si, men det er det sikkert noen som kommer til å prøve ut.

Som erfaren behandler er jeg også bekymret. Teambasert behandling med behandlerrotasjon innebærer faktisk at behandleren i det individuelle pasientbehandler-forholdet erstattes med standardiserte, kunnskapsbaserte behandlere omtrent som LEGO-figurer. Og da er jo ikke veien lang til ekte roboter...

Olaf Gjerløw Aasland

Legeforeningens forskningsinstitutt

\section{Inspirerende for folkehelseforskere}

Thomas W. Valente

Social networks and health

Models, methods, and applications. 277 s, tab,

ill. Oxford: Oxford University Press, 2010.

Pris GBP 33

ISBN 978-0-19-530101-4

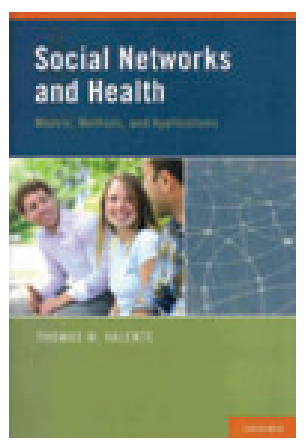

Forfatteren er professor i forebyggende medisin ved University of Southern California, USA. Han har bakgrunn i matematikk og kommunikasjon, og hans forskning fokuserer på nettverksanalyser, helsekommunikasjon og matematiske modeller innen folkehelsefeltet med evaluering av helsefremmende og forebyggende programmer. Forfatteren gir systematisk pedagogisk introduksjon til hovedteorier, metoder, modeller og funn fra forskning på nettverksanalyser av medisinske temaer og folkehelsetemaer. Målgruppen er spesielt forskningsgrupper, men også praktikere, klinikere og byråkrater som samarbeider med forskere på feltet.

Boken er svært godt pedagogisk lagt opp. Forfatteren sørger for å gi en systematisk forståelse av begreper og mål på struktur i sosiale nettverk og hvordan dette kan måles. Han bruker illustrasjoner som gir en intuitiv forståelse av komplekse sammenhenger. Formen tilfredsstiller både behov på høyt forskningsnivå og gir en økt forståelse for de som er mer praktisk opptatt av hva et verktøy som nettverksanalyser kan brukes til. Det er beskrivelser av hvordan analyser kan igangsettes og gjennomføres. Henvisninger til litteratur gir ytterligere «kokebokbeskrivelser» av fremgangsmåter. Bakerst får man en egen oversikt over betydningen av ulike begreper og eksempler på spørreskjema.

Sosiale nettverk, relasjonen mellom folk, er helt sentralt for å forstå både helseatferd, holdninger og spredning av kunnskap og sykdom. Selv om det er kompliserte strukturer som skal måles og beskrives, klarer forfatteren å formidle hvordan begrepene henger sammen. Boken er delt i tre deler; modeller, målemetoder og anvendelse. Man avslutter hvert kapittel med en pedagogisk oppsummering. Modelldelen gir en god klargjøring av ulike design, variabler og type datainnsamling. I målemetodedelen beskriver man konkret hvordan ulike strukturelle forhold kan beskrives og måles matematisk og illustreres i nettverksdiagrammer. Et individs sentralitet, posisjon, forhold til grupper i nettverket er relatert til individuell 